\title{
Assessment of Acute and Subacute Toxicity of the Total Dichloromethane-Ethanol Extract of Morinda morindoides (Baker) Milne-Redh (ETDE) on Rats
}

\author{
Boga Gogo Lucien*1, Bahi Calixte' ${ }^{1}$, Konkon N'Dri Gilles², Yapi Houphouët Félix', Djaman Allico Joseph ${ }^{1,3}$ and N'Guessan Jean David ${ }^{1}$ \\ 'Department of Biosciences, Biochemical Pharmacodynamy Laboratory, University Felix houphouët-Boigny, Abidjan 22, Côte d'Ivoire, Africa. \\ 2Department of Biosciences, Botanical Laboratory, University Felix houphouët-Boigny, Abidjan 22, Côte d'Ivoire, Africa. \\ ${ }^{3}$ Department of Clinical and Basic Biochemistry, Pasteur Institute of Côte d'Ivoire, Abidjan 04, Côte d'Ivoire, Africa.
}

\begin{abstract}
Context: ETDE shown good antihypertensive and antioxidant activities in rats made hypertensive. This present study aims to assess its toxicity. Aims: This study was designed to study the toxicity of dichloromethaneethanol extract of Morinda morindoides. Settings and Design: Toxicological activity in vivo. Methods and Material: Alkaloids were characterized from reagents of Bouchardat, flavonoids by reacting the cyanidrine, tannins by the reagent Stiasny, polyphenols by reacting ferric chloride, quinones by the reagent Bornstraëgen, sterols and polyterpenes by the reaction of Libermann and saponins by observing the foam after agitation of the extract. Acute and subacute toxicity were studied using respectively 423 and 407 OECD guidelines for testing of chemicals. Statistical analysis used: The graphical representation of the data was performed using the Graph Pad Prism 5.0. The mean value is accompanied by the standard error of the mean (Mean \pm SEM). The difference between the two values is considered significant when $P<0.001$. Statistical analysis of results was performed using analysis of variance (ANOVA). Results: The phytochemical screening showed the presence in the ETDE of polyphenols, alkaloids, flavonoids, sterols and polyterpenes. The toxicological study shows that ETDE has a $\mathrm{LD}_{50}$ between 2000 and $5000 \mathrm{mg} / \mathrm{kg}$ bw therefore classified in the hazard category 5. The administration of ETDE at repeated dose for 28 days did not significantly affect the weight gain, hematological and biochemical parameters of rats. Conclusion: ETDE toxicity is relatively low with $\mathrm{LD}_{50}$ between 2000 and $5000 \mathrm{mg} / \mathrm{kg}$ bw. It does not cause damage to the heart, liver and kidney. ETDE can be used without risk of intoxication.
\end{abstract}

Key words: Acute toxicity, Morinda morindoides, Subacute toxicity, Damage, Weight gain.

\section{SUMMARY}

- ETDE is a product that can be used without risk of poisoning
- ETDE does not cause damage to the heart, kidney and liver of animals.

- ETDE does not affect the immune system of animals.

- The absence of saponins in the ETDE could justify its non-toxicity.

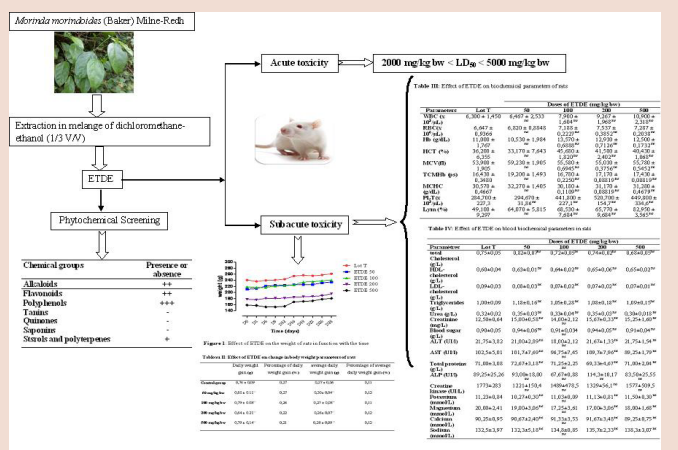

PICTORIAL ABSTRACT

Abbreviations used: ETDE: Total Dichloromethane-Ethanol Extract of Morinda morindoides.

Correspondence:

Mr. Boga Gogo Lucien, Department of Biosciences, Biochemical Pharmacodynamy Laboratory, University Felix houphouët-Boigny, P.O.Box 582, Abidjan 22, Côte d'Ivoire, Africa.

Email: bogagogo@yahoo.fr DOI : 10.5530/pj.2015.6.10

\section{INTRODUCTION}

The use of plants especially for therapeutic purposes is growing around the world, mainly in countries like Côte d'Ivoire, which is known for its richness in plants. Several factors explain the greater use often irrational, anarchic and uncontrolled. Therefore, the share of poisoning related to the use of plants is not negligible. Plants, because they are natural, are mistakenly considered non-hazardous and the population uses there in very varied and numerous contexts. Natural products are of great importance in the development of new pharmaceutical products or plant protection products, ${ }^{1,2}$ but many studies have shown that these products contain potential toxic effects. ${ }^{3,4}$ It is therefore essential, before use as a therapeutic drug form said plant extract in the traditional environment, to conduct its toxicological study to assess its safety for use without risk of poisoning. Morinda morindoides is a woody plant used by traditional practioner in Ivory Coast for the treatment of various illnesses. The work of Boga et al ${ }^{5}$ showed that the total dichloromethane-ethanol extract of this plant has a very good antioxidant activity in rats made hypertensive by adrenaline. Our previous study had shown significant antihypertensive activity of the dichloromethane-ethanol extract of M. morindoides in rabbit. ${ }^{6}$ The present study aims to study the acute and subacute toxicity of the dichloromethane-ethanol extract of Morinda morindoides.

\section{SUBJECTS AND METHODS}

\section{SUBJECTS}

White albino male and female rats, Wistar strain aged 2 to 3 months are used for the study of oxidative stress of the extract. The rats were kept in plastic cages with stainless steel covers containing a bed of wood chips renewed every two days. The animals are fed regularly with rat pellets and received standard tap water as the drinking water in stainless steel cylinders. The plant material is constituted by leaves of Morinda morindoides (Baker) Milne-Redh., collected to Gbahiri in the municipality of Lakota, South-western city of Côte d'Ivoire, between January and February 2012. These leaves were dried and powdered for the preparation of the extract. 


\section{METHODS}

\section{Preparation of the extract}

The total dichloromethane-ethanol extract of Morinda morindoides (Baker) Milne-Redh. (ETDE) was prepared according to the method

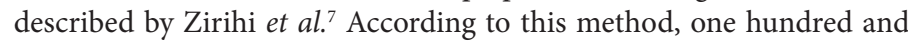
fifty grams (150 g) of powder of Morinda morindoides (Baker) MilneRedh. were dissolved in eight hundred milliliters $(800 \mathrm{~mL})$ of a mixture of dichloromethane-ethanol solvent $(1 / 3(\mathrm{~V} / \mathrm{V}))$. The mixture is homogenized for 24 hours at laboratory temperature $\left(25-30^{\circ} \mathrm{C}\right)$ using a magnetic stirrer IKAMAG RCT. The homogenate is filtered twice on cotton wool and once on Whatman $3 \mathrm{~mm}$ paper filter. The recovered filtrate is evaporated using a BÜCHI rotary evaporator. We got a greenish paste that forms the total dichloromethane-ethanol extract of Morinda morindoides (Baker) Milne-redh. (ETDE). Different doses for testing were prepared from this extract.

\section{Quantitative Analysis of the ETDE}

The different groups of ETDE were characterized using the techniques described in the work of Békro et al. ${ }^{8}$

\section{Search of total polyphenols}

The total polyphenols were characterized by the reaction with ferric chloride. These compounds form with ferric chloride $\left(\mathrm{FeCl}_{3}\right)$, a colorful blue-black or green precipitate. The assessment of this coloration is made with respect to a control test with a phenolic compound reference. At 2 $\mathrm{mL}$ of plant extract are added a few drops of alcoholic solution of ferric chloride $2 \%$. The appearance of a blue-black color more or less dark green indicates the presence of polyphenol derivatives.

\section{Search of alkaloids}

Alkaloids were characterized from Buchardat reagent (reagent iodoiodide) and Dragendorff (reagent potassium iodo-bismuthate). Six (6) $\mathrm{mL}$ of ETDE were evaporated to dryness and the residue taken up in 6 $\mathrm{ml}$ of alcohol at $60^{\circ} \mathrm{C}$. The addition of 2 drops of Dragendorff reagent on the alcoholic solution caused an orange precipitate. The appearance of a reddish brown precipitate following the addition of 2 drops of reagent Buchardat indicates a positive reaction.

\section{Search of flavonoids}

Flavonoids were detected by reaction with cyanidin. Two (2) $\mathrm{mL}$ of ETDE were evaporated to dryness and the residue taken up in $5 \mathrm{~mL}$ of hydrochloric alcohol diluted 2 times. 2-3 magnesium chips are added which caused a release of heat and a purplish color. The addition of 3 drops of isoamyl alcohol has intensified this coloration, which confirmed the presence of flavonoids.

\section{Search of sterols and polyterpenes}

Sterols and polyterpenes have been characterized by the reaction of Libermann. Five (5) $\mathrm{mL}$ of ETDE were evaporated on a sand bath. The residue obtained was dissolved in hot 1 acetic $\mathrm{mL}$ d'anhydride then 0.5 $\mathrm{mL}$ of concentrated sulfuric acid were added. There was appearing at the interface, a purple purplish ring, which turned blue to green. This indicated a positive reaction.

\section{Search of tannins}

Catechin tannins were sought from Stiasny reagent. Five (5) mL of ETDE were evaporated to dryness. The residue obtained are added $15 \mathrm{ml}$ of Stiasny reagent and the mixture was kept in a water bath at $80^{\circ} \mathrm{C}$ for 30 minutes. The observation of a precipitate in large flakes characterizes catechin tannins. For gallic tannins, the mixture is filtered and the collected filtrate is saturated with sodium acetate. The appearance of a deep blue-black color, after adding 3 drops of $\mathrm{FeCl}_{3}$ sign the presence of gallic tannins.

\section{Search of quinones}

Quinone substances have been characterized from Bornstraëgen reagent. Two (2) $\mathrm{mL}$ of ETDE were evaporated to dryness. The residue obtained was triturated in $5 \mathrm{ml}$ of hydrochloric acid 1/5. The triturate is poured into a test tube and heated in a water bath for 30 minutes. After cooling, it is extracted with $20 \mathrm{~mL}$ of chloroform. The appearance of a red or violet color after addition of $0.5 \mathrm{ml}$ of dilute ammonia twice to the chloroform solution, is the sign of the presence of quinones.

\section{Search of saponins}

Research saponins, $10 \mathrm{~mL}$ of ETDE were poured into a test tube, the tube is shaken for 15 seconds and allowed to stand for 15 minutes. Persistent foam height greater than $1 \mathrm{~cm}$ indicates the presence of saponins.

\section{Assessment of acute toxicity of ETDE}

The acute toxicity was investigated using the OECD Guideline $423^{9}$ for testing of chemicals. This method is a sequential process using three animals of one sex by step. Depending on the mortality and/or moribund state of animals, two to four steps are needed to assess the average acute toxicity of the test substance.

Aged female rats 3 to 4 months and weighing between 136.56 and 196.86 grams on average were used for experimentation. We did not have information on the toxicity of ETDE so we started the test with a dose of 300 $\mathrm{mg} / \mathrm{kg}$ bw.

Three rats deprived of food during the night but no water, are weighed and then were given orally $1 \mathrm{ml}$ of ETDE at a dose of $300 \mathrm{mg} / \mathrm{kg}$ bw as a single dose using a cannula intubation. After administration of ETDE, the three are again fasted for three hours before giving them food. They are observed individually the first thirty minutes, periodically during the first 24 hours after treatment. They were then observed daily for up to 14 days. 24 hours after administration of the ETDE at a dose of $300 \mathrm{mg} / \mathrm{kg}$ bw, no mortality and no moribund were observed, we have gone to the dose of $2000 \mathrm{mg} / \mathrm{kg}$ bw. After this dose, there was observed no mortality and no moribund. We then moved at a dose of $5000 \mathrm{mg} / \mathrm{kg}$ bw. Then three rats are treated in the same way.

\section{Evaluation of subacute toxicity}

Guideline $407 \mathrm{OECD}^{10}$ for testing of chemicals, with some modifications, was used for this study. The test substance is administered daily oral (gavage) at different dose levels of several batches of animals at the rate of one dose level per group, for a period of 28 days. 20 rats aged 2 to 3 months and weighing between 158.25 and 257.57 grams on average were used. The rats were divided into 5 groups of 4 rats each according to their weight. Rats in the control group (group 1) received individually by gavage daily 1 $\mathrm{ml}$ of distilled water for 28 days. The four lots (Lots 2, 3, 4 and 5) received by gavage 50 respectively; 100; 200 and $500 \mathrm{mg} / \mathrm{kg}$ bw ETDE daily for 28 days. The volume of extract administered daily in a single dose was $2 \mathrm{ml}$ per $100 \mathrm{~g}$ body weight. The experiment was conducted in accordance with the principles of good laboratory practice. During the 28 days of treatment, the animals were observed daily for clinical signs and symptoms of toxicity and death, before, immediately and 3 hours after administration of the extract. The $29^{\text {th }}$ day or the day after the last day of treatment, blood is taken from rat's tail docking for hematological and biochemical analyzes. Rats were weighed every three to four days to determine the effect of the extract on the weight gain of animals. 


\section{Assays of haematological parameters}

The hematological analysis was carried out using an automatic hematology analyzer (Sysmex KX-21). The parameters such as: the counting of Red blood cells (RBC), the number of White blood cells (WBC), Hemoglobin (Hb), Hematocrit (HCT), Mean corpuscular volume (MCV), Mean corpuscular hemoglobin $(\mathrm{MCH})$, Mean corpuscular hemoglobin concentration $(\mathrm{MCHC})$, platelet count and the percentage of cells were determined.

\section{Assays of biochemical parameters}

The blood contained in the dry tubes was centrifuged using a centrifuge at $3000 \mathrm{rpm} / \mathrm{min}$ for 5 minutes. The resulting serum was removed and stored at $-20^{\circ}$ for analysis of serum parameters of living kidney, liver and heart with the analyzer COBAS integral 400 plus. The protocol for each assay was preset and then incorporated into the device during the assays. We assayed Aspartate aminotransferase (AST), Alanine aminotransferase (ALT), Alkaline phosphatase (ALP), Blood glucose, Blood urea, Creatinine, Creatine kinase (CK), Total protein (TP), Total cholesterol (Chol-T), HDL cholesterol (HDL-C), LDL-cholesterol (LDL-c) and the blood electrolytes: $\mathrm{K}^{+}, \mathrm{Ca}^{2+}, \mathrm{Mg}^{2+}$ and $\mathrm{Na}^{+}$.

\section{RESULTS}

\section{Chemical composition of ETDE}

The phytochemical screening of ETDE revealed the presence of large chemical groups such as alkaloids, flavonoids, polyphenols, sterols and polyterpenes. It is clear from these results that the ETDE contains very high proportion of polyphenols, flavonoids and alkaloids but does not contain saponins, tannins and quinones (Table 1).

Table 1: Chemical composition of ETDE

\begin{tabular}{cc}
\hline Chemical groups & Presence or absence \\
\hline Alkaloids & ++ \\
Flavonoids & ++ \\
Polyphenols & +++ \\
Tanins & - \\
Quinones & - \\
Saponins & - \\
Stsrols and polyterpenes & + \\
\hline
\end{tabular}

\section{Acute toxicity of ETDE}

After administration of ETDE at doses ranging from 300 to $2000 \mathrm{mg} / \mathrm{kg}$ bw to rats, no signs of toxicity were observed during the 14 days of observation. As against the dose of $5000 \mathrm{mg} / \mathrm{kg}$ bw resulted dyspnea, anorexia, bleeding and death of animals.

\section{Subacute toxicity of ETDE}

\section{Effect of ETDE on body weight parameters of rats}

The results in Table 2 show that the control group had a daily weight gain of $0.74 \mathrm{~g}$ (percentage of daily weight gain of $0.26 \%$ ) and an average daily weight gain of $0.27 \mathrm{~g}$ (percentage of average daily weight gain of $0.11 \%$ ). The oral administration of ETDE at doses of 50,100, 200 and $500 \mathrm{mg} /$ $\mathrm{kg}$ bw did not significantly affect these parameters. And at doses of 50 , 100,200 and $500 \mathrm{mg} / \mathrm{kg}$ bw, the rats had respective daily weight gains of $0.85 ; 0.79 ; 0.64$ and $0.79 \mathrm{~g}$ (percentage of daily weight gain of $0.27 ; 0.26$; 0.22 and $0.21 \%$ ). As for average daily weight gains, they varied from 0.30 respectively; $0.27 ; 0.26$ and $0.28 \mathrm{~g}$ (percentage of average daily weight gain of $0.12 ; 0.11 ; 0.12$ and $0.12 \%)$. It is clear from these results that the ETDE had no significant effect on weight gain in rats.

During the first 6 days of feeding, the weight of rats decreased for all other doses except $500 \mathrm{mg} / \mathrm{kg}$ bw, the weight decline continued until the ninth day. After those days, growth resumed and developed normally from the control group until the last day of treatment (Figure 1).

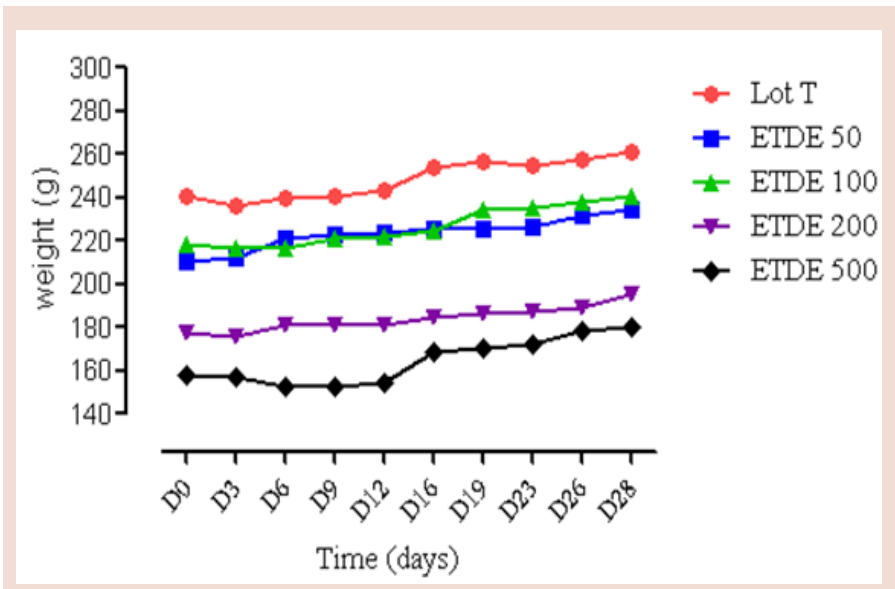

Figure 1: Effect of EDTE on the weight of rats in function with the time

\section{Effect of ETDE on hematological parameters in rats}

Hematology rats were measured after 28 days of treatment with ETDE. Rats received the ETDE by gavage at doses of 50,100,200, $500 \mathrm{mg} / \mathrm{kg}$ bw for lots 2, 3, 4, 5 and tap water for the control group. Blood is then collected in EDTA tubes by amputation of tail and analyzed using an automatic hematology analyzer (Sysmex KX-21). The effect of ETDE on hematological parameters in rats treated is presented in Table 3.

The results show that all hematologic parameters have not evolved significantly compared to the control group. At doses used in this experiment, the ETDE caused no significant change in blood parameters that are the White blood cells (WBC), Red blood cells (RBC), Hemoglobin $(\mathrm{Hb})$, Hematocrit (HCT), Mean corpuscular volume (MCV), Mean cor-

Table 2: Effect of ETDE on change in body weight parameters of rats

\begin{tabular}{ccccc}
\hline & $\begin{array}{c}\text { Daily weight } \\
\text { gain (g) }\end{array}$ & $\begin{array}{c}\text { Percentage of daily } \\
\text { weight gain (\%) }\end{array}$ & $\begin{array}{c}\text { Average daily weight } \\
\text { gain (g) }\end{array}$ & $\begin{array}{c}\text { Percentage of average } \\
\text { daily weight gain (\%) }\end{array}$ \\
\hline Control group & $0.74 \pm 0,09$ & 0.27 & $0.27 \pm 0,06$ & 0.11 \\
$\mathbf{5 0} \mathbf{~} \mathbf{~ g / k g ~ b w ~}$ & $0.85 \pm 0.11^{\mathrm{ns}}$ & 0.27 & $0.30 \pm 0,04^{\mathrm{ns}}$ & 0.12 \\
$\mathbf{1 0 0} \mathbf{~} \mathbf{~ g / k g ~ b w}$ & $0.79 \pm 0.08^{\mathrm{ns}}$ & 0.26 & $0.27 \pm 0,08^{\mathrm{ns}}$ & 0.11 \\
$\mathbf{2 0 0} \mathbf{~} \mathbf{~ g / k g ~ b w}$ & $0.64 \pm 0.21^{\mathrm{ns}}$ & 0.22 & $0.26 \pm 0,07^{\mathrm{ns}}$ & 0.12 \\
$\mathbf{5 0 0} \mathbf{~} \mathbf{~ g / k g ~ b w}$ & $0.79 \pm 0,14^{\mathrm{ns}}$ & 0.21 & $0.28 \pm 0,09^{\mathrm{ns}}$ & 0.12 \\
\hline
\end{tabular}

Data are expressed in mean \pm SEM; $(n=4)$; $n s, p<0.05$ : no significant difference compared with rats of control group. 
Table 3: Effect of ETDE on biochemical parameters of rats

\begin{tabular}{|c|c|c|c|c|c|}
\hline \multirow[b]{2}{*}{ Parameters } & \multirow[b]{2}{*}{ Lot T } & \multicolumn{4}{|c|}{ Doses of ETDE (mg/kg bw) } \\
\hline & & 50 & 100 & 200 & 500 \\
\hline WBC $(x 103 / \mu \mathrm{L})$ & $6.300 \pm 1.450$ & $6.467 \pm 2.533^{\mathrm{ns}}$ & $7.900 \pm 1.604^{\mathrm{ns}}$ & $9.267 \pm 1.968^{\mathrm{ns}}$ & $10.900 \pm 2.318^{\mathrm{ns}}$ \\
\hline $\operatorname{RBC}(\times 106 / \mu \mathrm{L})$ & $6.647 \pm 0.9366$ & $6.820 \pm 0.8848^{\mathrm{ns}}$ & $7.188 \pm 0.2227^{\mathrm{ns}}$ & $7.537 \pm 0.3852^{\mathrm{ns}}$ & $7.287 \pm 0.2038^{\mathrm{ns}}$ \\
\hline $\mathrm{Hb}(\mathrm{g} / \mathrm{dL})$ & $11.000 \pm 1.767$ & $10.530 \pm 1.984^{\mathrm{ns}}$ & $13.570 \pm 0.6888^{\mathrm{ns}}$ & $12.930 \pm 0.7126^{\mathrm{ns}}$ & $12.500 \pm 0.1732^{\mathrm{ns}}$ \\
\hline HCT (\%) & $36.200 \pm 6.355$ & $33.170 \pm 7.643^{\mathrm{ns}}$ & $45.680 \pm 1.820^{\mathrm{ns}}$ & $41.500 \pm 2.402^{\mathrm{ns}}$ & $40.430 \pm 1.068^{\mathrm{ns}}$ \\
\hline $\operatorname{MCV}(\mathbf{f l})$ & $53.900 \pm 1.905$ & $59.230 \pm 1.905^{\mathrm{ns}}$ & $55.580 \pm 0.6945^{\mathrm{ns}}$ & $55.030 \pm 0.3756^{\mathrm{ns}}$ & $55.780 \pm 0.5452^{\mathrm{ns}}$ \\
\hline TCMHb (ps) & $16.430 \pm 0.3480$ & $19.200 \pm 1.493^{\mathrm{ns}}$ & $16.780 \pm 0.2250^{\mathrm{ns}}$ & $17.170 \pm 0.08819^{\mathrm{ns}}$ & $17.430 \pm 0.08819^{\text {ns }}$ \\
\hline $\operatorname{MCHC}(\mathrm{g} / \mathrm{dL})$ & $30.570 \pm 0.4667$ & $32.270 \pm 1.405^{\mathrm{ns}}$ & $30.180 \pm 0.1109^{\text {ns }}$ & $31.170 \pm 0.08819^{\mathrm{ns}}$ & $31.280 \pm 0.4679^{\mathrm{ns}}$ \\
\hline $\operatorname{PLT}(x 103 / \mu \mathrm{L})$ & $284.700 \pm 227.3$ & $294.670 \pm 31.86^{\mathrm{ns}}$ & $441.800 \pm 227.1^{\mathrm{ns}}$ & $520.700 \pm 154.7^{\mathrm{ns}}$ & $449.800 \pm 334.6^{\mathrm{ns}}$ \\
\hline Lym (\%) & $49.100 \pm 9.297$ & $64.070 \pm 5.815^{\mathrm{ns}}$ & $68.530 \pm 7.684^{\mathrm{ns}}$ & $65.770 \pm 9.684^{\mathrm{ns}}$ & $82.950 \pm 3.565^{\mathrm{ns}}$ \\
\hline
\end{tabular}

Data are expressed as mean \pm SEM; $(n=5)$; ns (not significant, $\mathrm{p}<0.05)$; White blood cells $\left(\mathrm{x} 10^{3} / \mathrm{uL}\right)$; Red blood cells $\left(\mathrm{x} 10^{6} / \mathrm{uL}\right)$; Hemoglobin (g/dL); Mean corpuscular hemoglobin concentration (g/dL); Platelets (x10/uL); Lymphocyte (\%); Hematocrit (\%); Mean corpuscular volume (FL/cell).

Table 4: Effect of ETDE on blood biochemical parameters in rats

\begin{tabular}{|c|c|c|c|c|c|}
\hline \multirow[b]{2}{*}{ Paramètres } & \multirow[b]{2}{*}{ Lot T } & \multicolumn{4}{|c|}{ Doses of ETDE (mg/kg bw) } \\
\hline & & 50 & 100 & 200 & 500 \\
\hline Total Cholesterol (g/L) & $0.75 \pm 0.05$ & $0.82 \pm 0.07^{\mathrm{ns}}$ & $0.72 \pm 0.05^{\mathrm{ns}}$ & $0.74 \pm 0.02^{\mathrm{ns}}$ & $0.68 \pm 0.05^{\mathrm{ns}}$ \\
\hline HDL-cholesterol (g/L) & $0.60 \pm 0.04$ & $0.63 \pm 0.01^{\mathrm{ns}}$ & $0.64 \pm 0.02^{\mathrm{ns}}$ & $0.65 \pm 0.06^{\mathrm{ns}}$ & $0.65 \pm 0.02^{\mathrm{ns}}$ \\
\hline LDL-cholesterol (g/L) & $0.09 \pm 0.03$ & $0.08 \pm 0.03^{\mathrm{ns}}$ & $0.07 \pm 0.02^{\mathrm{ns}}$ & $0.07 \pm 0.02^{\mathrm{ns}}$ & $0.07 \pm 0.01^{\mathrm{ns}}$ \\
\hline Triglycerides $(\mathrm{g} / \mathrm{L})$ & $1.00 \pm 0.09$ & $1.18 \pm 0.16^{\mathrm{ns}}$ & $1.05 \pm 0.28^{\mathrm{ns}}$ & $1.08 \pm 0.18^{\mathrm{ns}}$ & $1.09 \pm 0.15^{\mathrm{ns}}$ \\
\hline Urea $(g / L)$ & $0.32 \pm 0.02$ & $0.35 \pm 0.03^{\mathrm{ns}}$ & $0.33 \pm 0.04^{\mathrm{ns}}$ & $0.35 \pm 0.03^{\mathrm{ns}}$ & $0.30 \pm 0.018^{\mathrm{ns}}$ \\
\hline Creatinine $(\mathrm{mg} / \mathrm{L})$ & $12.50 \pm 0.64$ & $15.00 \pm 0.58^{\mathrm{ns}}$ & $14.00 \pm 2.12^{\mathrm{ns}}$ & $15.67 \pm 0.33^{\mathrm{ns}}$ & $15.25 \pm 1.60^{\mathrm{ns}}$ \\
\hline Blood sugar (g/L) & $0.90 \pm 0.05$ & $0.94 \pm 0.06^{\mathrm{ns}}$ & $0.91 \pm 0.034^{\mathrm{ns}}$ & $0.94 \pm 0.05^{\mathrm{ns}}$ & $0.91 \pm 0.04^{\mathrm{ns}}$ \\
\hline ALT (UI/l) & $21.75 \pm 3.82$ & $21.00 \pm 2.89^{\mathrm{ns}}$ & $18.00 \pm 2.12^{\mathrm{ns}}$ & $21.67 \pm 1.33^{\mathrm{ns}}$ & $21.75 \pm 1.54^{\mathrm{ns}}$ \\
\hline $\operatorname{AST}(\mathrm{UI} / \mathbf{l})$ & $102.5 \pm 5.01$ & $101.7 \pm 7.69^{\mathrm{ns}}$ & $96.75 \pm 7.45^{\mathrm{ns}}$ & $109.7 \pm 7.96^{\mathrm{ns}}$ & $89.25 \pm 1.79^{\mathrm{ns}}$ \\
\hline Total proteins $(\mathrm{g} / \mathrm{L})$ & $71.00 \pm 3.08$ & $72.67 \pm 3.18^{\mathrm{ns}}$ & $71.25 \pm 2.25^{\mathrm{ns}}$ & $69.33 \pm 4.67^{\mathrm{ns}}$ & $71.00 \pm 2.04^{\mathrm{ns}}$ \\
\hline $\operatorname{ALP}(\mathrm{UI} / \mathrm{l})$ & $89.25 \pm 25.26$ & $93.00 \pm 18.00^{\text {ns }}$ & $67.67 \pm 0.88^{\mathrm{ns}}$ & $114.3 \pm 10.17^{\mathrm{ns}}$ & $83.50 \pm 25.55^{\mathrm{ns}}$ \\
\hline Creatine kinase (UI/L) & $1773 \pm 283$ & $1221 \pm 150.4^{\mathrm{ns}}$ & $1489 \pm 478.5^{\mathrm{ns}}$ & $1329 \pm 56.1^{\mathrm{ns}}$ & $1577 \pm 509.5^{\text {ns }}$ \\
\hline Potassium (mmol/L) & $11.23 \pm 0.84$ & $10.27 \pm 0.30^{\mathrm{ns}}$ & $11.03 \pm 0.09^{\mathrm{ns}}$ & $11.13 \pm 0.81^{\mathrm{ns}}$ & $11.50 \pm 0.30^{\mathrm{ns}}$ \\
\hline Magnesium (mmol/L) & $20.00 \pm 2.41$ & $19.00 \pm 3.06^{\mathrm{ns}}$ & $17.25 \pm 3.61^{\mathrm{ns}}$ & $17.00 \pm 3.06^{\mathrm{ns}}$ & $18.00 \pm 1.68^{\mathrm{ns}}$ \\
\hline Calcium (mmol/L) & $90.25 \pm 0.95$ & $90.67 \pm 2.40^{\mathrm{ns}}$ & $91.33 \pm 3.53^{\mathrm{ns}}$ & $91.67 \pm 3.48^{\text {ns }}$ & $89.25 \pm 0.75^{\mathrm{ns}}$ \\
\hline Sodium $(\mathrm{mmol} / \mathrm{L})$ & $132.5 \pm 3.97$ & $132.3 \pm 5.18^{\mathrm{ns}}$ & $134.8 \pm 0.85^{\mathrm{ns}}$ & $135.7 \pm 2.33^{\mathrm{ns}}$ & $138.3 \pm 3.07^{\mathrm{ns}}$ \\
\hline
\end{tabular}

Data are expressed as mean \pm SEM $(n=4)$.; ns (not significant); ALT: Aspartate aminotransferase (U/1); ALT: Alanine aminotransferase (U/l); Urea (mg/l); Creatinine (mg/l), LDH: Lactate dehydrogenase (U/l); CK: Creatine kinase (U/l); PAL: Alkaline Phosphatase (U/L); Total proteins (g/l); Cholesterol (g/l), Triglycerides (g/l); HDL: High-density lipoprotein; LDL: Low-density lipoprotein (g/l).

puscular hemoglobin concentration (MCHC), Platelets (PLT) and Lymphocytes (Lym) compared to the control group. The values of GR (6.647 $\left.\pm 0.94 \times 10^{6} / \mu \mathrm{L}\right), \mathrm{Hb}(11 \pm 1.77 \mathrm{~g} / \mathrm{dL})$, hematocrit $(36.2 \pm 6.36 \%)$ are in the range of usual values. We note that the percentage of lymphocytes nearly doubled, but this increase was not significant effect. This is also true for the platelets.

Effect of ETDE on biochemical parameters of rats

Table 4 shows the effect of ETDE on biochemical parameters in rats. The results show that of the 16 biochemical parameters measured during the treatment period (28 days), no parameters have changed significantly. At doses of 50, 100, 200, $500 \mathrm{mg} / \mathrm{kg}$ bw, ETDE resulted in no significant change settings.

\section{DISCUSSION}

The results of the phytochemical study of the extract of ETDE show the presence of alkaloids, flavonoids, polyphenols, sterols and polyterpenes. These results disagree with those of the methanol extract of Morinda morindoides witch contained saponins but not alkaloids ${ }^{11}$ and those of various extracts (aqueous, ethanol, ethyl acetate and hexane extracts) of Morinda morindoides. ${ }^{12}$

After administration of ETDE at doses ranging from 300 to $2000 \mathrm{mg} / \mathrm{kg}$ bw to rats, no signs of toxicity were observed during the 14 days of observation. As against the dose of $5000 \mathrm{mg} / \mathrm{kg}$ bw resulted dyspnea, anorexia, bleeding and death of animals. According to OECD Guideline 423 line for testing chemicals, ETDE has lethal dose $50\left(\mathrm{LD}_{50}\right)$ between 2000 and 
$5000 \mathrm{mg} / \mathrm{kg}$ bw. In principle, this process is not intended to determine a value of the precise $\mathrm{LD}_{50}$, but serves as a suggestion for the classification of the crude extract based on the prediction of the dose at which animals have to survive. ${ }^{13}$ The ETDE can be classified in the hazard category 5, acute toxicity is relatively low but may, under certain conditions, be dangerous for vulnerable populations.

The administration of ETDE at doses of 50, 100, 200 and $500 \mathrm{mg} / \mathrm{kg}$ bw had no significant effect $(\mathrm{p}<0.05)$ on weight parameters of animals compared to control group, which means that ETDE has a negligible effect on the growth of animals. In general; body weight gain and mouse internal organs changes reflect the toxicity after exposure to toxic substances. ${ }^{14}$ Body weight changes are indicators of adverse effects of chemical drugs and products, and it will be important if the loss of body weight is more than $10 \%$ from the initial weight. ${ }^{15,16}$ However, it is reported that increases in body weights of the animals are more closely related to the accumulation of fat rather than toxic effects of drugs or chemicals ${ }^{17}$ The reductions in body weights observed the first days of treatment may be associated with normal physiological responses of adaptation of animals to the extract ${ }^{18}$ but also to stress caused by treatment. ${ }^{19}$

Treatment of rats with ETDE at repeated doses for 28 days, caused no significant change $(\mathrm{p}<0.001)$ in hematological and biochemical parameters in rats treated compared to the control group. Red blood cells (RBC), White blood cells (WBC), Platelets (PLT), Lymphocytes (LYM), Hemoglobin $(\mathrm{Hb})$ and other hepatocytes are the most sensitive target of toxic compounds and is an important index of pathological and physiological state of human and animal. ${ }^{20}$ In our study, there were no significant changes in these parameters. Or a modification of these parameters provides information on the human toxicity when these data are derived from studies in animals. ${ }^{21}$ Changing these parameters also determine the safety of a substance subject to a toxicological study. RBC and WBC rates have not significantly different compared to the control group. Platelets and lymphocytes have seen their value almost doubled; however, these values are within the ranges of normal values. ${ }^{22}$ The ETDE therefore did not affect the immune system; lymphocytes are the main effector cells of the immune system. ${ }^{23}$

Our results show that the activities of enzymes such as the ALT, AST and ALP were not disturbed by ETDE. These enzymes are liver markers whose activities increase in liver toxicity. ${ }^{24,25}$ Their concentration in serum informs about a hepatocyte injury. ${ }^{26}$

ALT is an enzyme specific to the liver in dogs, rats, rabbits, cats and primates. ${ }^{27}$ It can provide a quantitative assessment of the degree of damage to the liver. ${ }^{28}$ Our results show that ETDE caused no damage to the liver as shown Sucheta et al. ${ }^{29}$ Urea and creatinine are markers of renal function ${ }^{25}$ have not seen their rates varied by ETDE.

No significant change in the $\mathrm{CK}$ and $\mathrm{LDH}$ activities was observed. These enzymes are markers of cardiac function..$^{30}$ Our results show that ETDE, at the doses used, did not provoked significantly change $(\mathrm{p}<0.001)$ of serum biochemical values of these parameters compared with rats in the control group, suggesting that the ETDE did not affect kidney, or heart, or the liver. Blood sugar has not changed significantly during treatment, suggesting that ETDE did not affect the blood sugar control system. ETDE was also not significantly changed $(\mathrm{p}<0.001)$, serum values of HDL-cholesterol (HDL-C), LDL-cholesterol (LDL-C), total cholesterol and triglycerides. However, a slight decrease in LDL-c rates and a slight increase in HDL-c rates are observed compared to the control group. The ETDE could therefore prevent cardiovascular complications.

Blood electrolytes, such as calcium $\left(\mathrm{Ca}^{2+}\right)$, potassium $\left(\mathrm{K}^{+}\right)$, magnesium $\left(\mathrm{Mg}^{2+}\right)$ and sodium $\left(\mathrm{Na}^{+}\right)$, no significant variation $(\mathrm{p}<0.001)$ were noted with respect to the control group. That suggests that ETDE did not influence the hemodynamic balance. It is clear from our study that at doses used, ETDE is not toxic and could be used without causing damage to the body. Our results are consistent with those of Balogun and Akinloye ${ }^{11}$ which showed that the administration of the methanol extract of Morinda morindoides is not harmful to rats at the same doses. The study of subacute toxicity showed that ETDE preserves the integrity of vital organs.

\section{CONCLUSION}

ETDE is an extract whose toxicity is relatively low with $\mathrm{LD}_{50}$ between 2000 and $5000 \mathrm{mg} / \mathrm{kg}$ bw. This extract does not cause damage to the toxic target organs such as the heart, liver and kidney. The ETDE can be used without risk of intoxication.

\section{ACKNOWLEDGEMENT}

We thank Mr. Kouangbé Mani Adrien, PhD student in Pharmacology of Natural Substances, Biosciences Department, University Félix Houphouët-Boigny (Côte d'Ivoire) for its technical assistance.

\section{CONFLICT OF INTEREST}

The authors declare that they have no conflict of interest.

\section{REFERENCES}

1. Gilani $A H$, Rahman AU. Trends in ethnopharmacology. Journal of Ethnopharmacology 2005; 100(1): 43-9.

2. Patwardhan B. Ethnopharmacology and dry discovery. Journal of Ethnopharmacology 2005; 100(1): 50-2.

3. Pak E, Esrason KT, Wu VH. Hepato-toxicity of herbal remedies: an emerging dilemma. Progress in Transplantation 2004; 14(2): 91-6.

4. Marcus DM, Snodgrass WR. Do no harm avoidance of herbal medecines during pregnancy. Obstetrics and Gynecology 2005; 105(5): 1119-22.

5. Boga GL, Bahi C, Kouangbé MA, Djaman AJ, N'Guessan JD. In vivo and in vitro antioxidant activity of the total dichloromethane-ethanol extract of Morinda morindoides (Baker) Minle-Redh (ETDE) (Rubiaceae). IJBCRR. 2015; 7(4): 182-91.

6. Boga GL, Trebissou ND, Bahi C, Kouangbé MA, Zirihi GN. Effect of dichloromethane-ethanol extract of Morinda morindoides (Baker) Milne-redhead (Rubiaceae) (ETDE) on rabbit carotid blood pressure. IJABPT. 2013; 4(3): 158-65.

7. Zihiri GN, Kra AK, Guede-Guina F. Evaluation de l'activité antifongique de Microglossa pyrifolia (LA MARCK) O. KUNTZE (Astéraceae) "PYMI» sur la croissance in vitro de Candida albicans. Rev Med et Pharm Afr. 2003; 17(3): 11-8.

8. Békro YA, Békro JAM, Boua BB, Tra BFH, Ehilé EE. Etude ethnobotanique et screening phytochimique de Caesalpinia benthamiana (Baill.) (Caesalpiniaceae). Rev. Sci. Nat. 2007; 4(2): 217-25.

9. OCDE. Lignes directrices de I'OCDE pour les essais de produits chimiques n423: toxicité orale aiguë-Méthode par classe de toxicité aiguë; 2001. p. 14.

10. OCDE. Lignes directrices de I'OCDE pour les essais de produits chimiques $n^{\circ} 407$ : Etude de toxicité orale à dose répétée pendant 28 jours sur les rongeurs; 2006. p. 14

11. Balogun AE, Akinloye ID. Biochemical effects of methanolic extract of Morinda morindoides and Morinda lucida leaves on lipid profile, bilirubin and some markers enzymes. Asian J Med Res. 2012; 1(1): 12-6.

12. Touré A, Bahi C, Ouattara K, Djaman AJ, Coulibaly A. Phytochemical screening and in vitro antifungal activities of extracts of leaves of Morinda morindoides (Morinda, Rubiaceae). Journal of Medicinal Plants Research 2011; 5(31): 6780-6.

13. Roopashree TS, Raman D, Rani RHS, Narendra C. Acute oral toxicity studies of antipsoriatic herbal mixture comprising of aqueous extracts of Calendula officinalis, Momordica charantia, Cassia tora and Azadirachta indica seed oil. Thai J pharm. Sci. 2009; 33(2-3): 74-83.

14. Carol SA. Acute, subchronic and chronic toxicology. In CRC Handbook of Toxicology Michael JD, mannfred AH, Eds CRC Press Inc; 1995. 51-104.

15. Raza M, Al-Shabanah OA, El-Hadilyah TM, Al-Majed AA. Effect of prolonged vigabatrin treatment on haematological and biochemical parameters in plasma, liver and kidney of Swiss albino mice. Sci. pharm. 2002; 70(2): 135-45.

16. Teo SD, Stirling S, Thomas A, Kiorpes A, Vikram K. A 90-day oral gavage toxicity study of D-methlphenidate and D, L methylphenidate in Sprague-dawley rats. Toxicology 2002; 179(3): 183-96.

17. Harizal SN, Mansor SM, Hasnan J, Tharakan JKJ, Abdullah J. Acute toxicity study of the standardized methanolic extract of Mitragyna speciosa Korth in Rodent. J. Ethnopharmacol. 2010; 131(2): 404-9.

18. Rhiouani H, El-Hilalya J, Israili ZH, Lyoussia B. Acute and subchronictoxicity of an aqueous extract of the leaves of Hernaniara globra in rodents. J. Ethnopharmacol. 2008; 118(3): 378-86. 
19. Harris MI, Flegal KM, Cowie CC, Eberhardt MS, Goldstein DE, Little RR, et al. Prevalence of diabetes, impaired fasting glucose, and impaired glucose tolerance in U.S. adults. The Third National Health Nutrition Examination Survey; 1988-1994. Diabetes Care 1998; 21(4): 518-24.

20. Mukinda JT, Syce JA. Acute and chronic toxicity of the aqueous extract of Artemisia afrain rodents. Journal of Ethnopharmacology 2007; 112(1): 138-44.

21. Olson H, Betton G, Robinson D, Thomas K, Monro A, Kolaja G, et al. Concordance of toxicity of pharmaceuticals in humans and in animals. Regulatory Toxicology and Pharmacology 2000; 32(1): 56-67.

22. Boussarie D. Consultation des petits mammifères de compagnie. Maison-Alfort: Editions du point Vétérinaire; 2003. p. 218.

23. Téguia A, Telefo PB, Fotso RG. Growth performances; organ development and blood parameters of rats feed graded levels of steeped and cooked taro tuber (Colocasia esculenta varesculenta) meal. Livestock res Rural Dev. 2007; 19(6): 1-7.

24. Rahman MF, Siddiqui MK, Jamil K. Effects of Vepacide (Azadirachta indica) on aspartate and alanine aminotransferase profiles in a subchronic study with rats.
Human and Experimental Toxicology 2001; 20(5): 243-9.

25. Hilaly JE, Israili ZH, Lyouss B. Acute and chronic toxicological studies of Ajuvaiva in experimental animals. J. Ethnopharmacol. 2004; 91(1): 43-50.

26. Kumar SD, Kumar OP. Evaluation of antioxidant potential, phenolic and flavonoid content of Hibiscus tiliaceus flowers. EJEAF Chem. 2008; 7(4): 2863-71.

27. Farah DP, Hazilawati H, Rosly SM, Shanmugavelu S, Noordin MM. Expression of circulating CD146 associated with endovascular dysfunction in adenine-induced chronic renal failure in rats using an Eva Green real-time RT-PCR assay. Pertanika J. Trop. Agric. Sci. 2011; 34(2): 381-91.

28. Al-Mamary M, Al-Habori M, Al-Aghbari AM, Baker MM. Investigation into the toxicological effects of Catha edulis leaves: a short -term study in animals. Phytother. Res. 2002; 16(2): 127-32.

29. Sucheta P, Dandakar Rane SA. Praticals and vivia in Medical Biochemistry. Elsevier, New delhi; 2004. p. 122-6.

30. Coulibaly A, Djih BN, Dombia I, Yapi HF, Djaman AJ. Valeurs sériques enzymatiques du cœur chez les lapins traités par Phyllanthus amarus (Euphorbiacées): phytothérapie 2010; 8(6): 348-52.

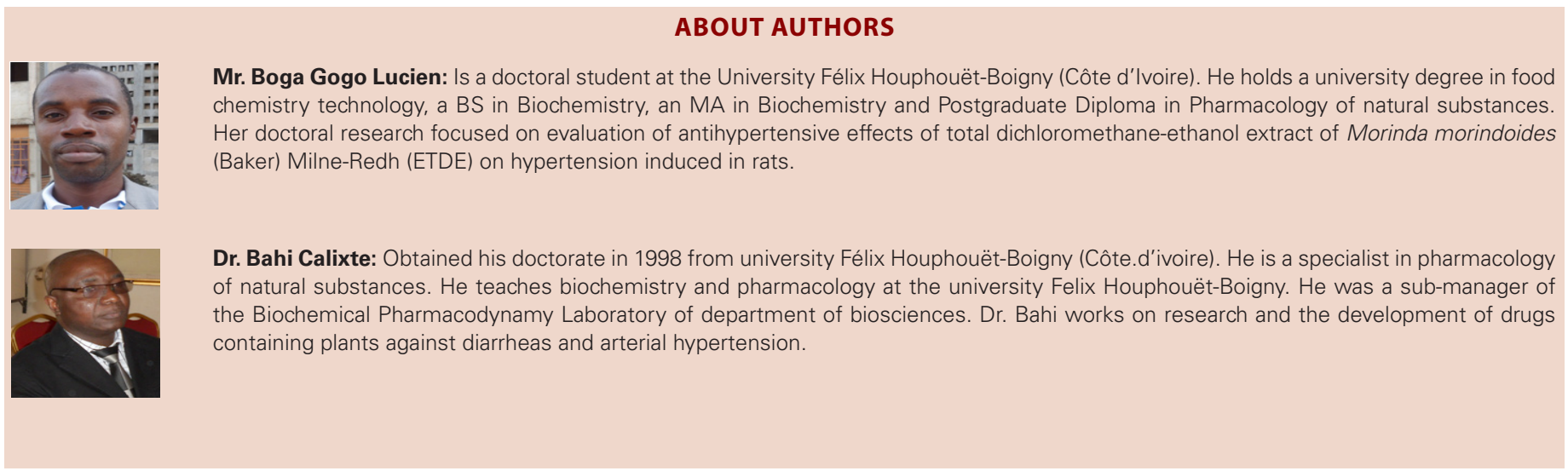

